\title{
The Effect of Environmental Turbulence, Social Capital, and Organizational Resilience on Tourism SME Performance: Impact of Pandemic COVID-19
}

\author{
Galih Trias Farobi ${ }^{1}$, Mohammad Hamsal ${ }^{2}$ \\ \{Farobiobi@gmail.com ${ }^{1}$, mhamsal@binus.edu² $\}$

\begin{abstract}
Master Degree Program of Science Management, Faculty of Business and Economics, University of Indonesia, Indonesia ${ }^{1}$, Management Department, Binus Business School Doctor of Research in Management, Bina Nusantara University, Indonesia ${ }^{2}$
\end{abstract}

\begin{abstract}
Tourism has grown into a leading sector in driving the economy both locally and internationally. However, the COVID-19 pandemic came and gave a domino effect on Government's vital sector, which include the tourism sector. Within these days, turbulent and uncertain environment organizations are susceptible to disruptive events that can undermine stability and security, this much riotous occurrences negatively affect the execution of organizations. Resiliency is the ability of a process to assert its indistinguishability and adjust its crucial structure and function in the look of disruption. And using social capital we argue that networks and resources available to firms complete up their linking to others is also a critical aspect of resiliency. This conceptual study aims to examine the role of Environmental turbulence, Social Capital, and Organizational Resilience, leading to improve tourism SME performance. This research will be conducted for SME in Tourism Sector in Indonesia using PLS-SEM as Methodology.
\end{abstract}

Keywords: Environmental Turbulence, Social Capital, Organizational Resilience, Tourism SME Performance, Tourism Sector, COVID-19

\section{Introduction}

Tourism has grown into a leading sector in driving the economy both locally and globally. The growth of tourism industry has been significant, due to this industry has gotten one of the biggest monetary divisions on the planet. Meanwhile, Indonesia has around 17.000 large and small islands, about 6.000 of which are uninhabited. These islands spread in the equator with a tropical climate. By seeing this condition, Indonesia has enormous tourism potential, ranging from natural scenery in the form of beaches to culinary [1]. According to data from the United Nations World Tourism (UNWTO) in 2019, the tourism sector produced 10,4\% of the GDP of the world average. Besides, the UNWTO also noted that international travel in 2018 grew by 6\%, with total international travel in 2018 grew by $6 \%$, with total international tourists that travel to the Asia Pacific growing by $7 \%$. This phenomenon will have impact on countries in the Asia Pacific, Indonesia is one of them, which can make the tourism sector one of the main drivers of the country's economic growth.

However, the last March, the COVID-19 pandemic came and gave a domino effect on several Government's vital sectors, which also include the tourism sector. The tourism sector in Indonesia should be one of the main foreign exchange contributors, However, because of COVID-19, the tourism sector has fallen drastically [2]. According to Detiknews (2020), Indonesia's economic growth on Q2 2020 contracted to -5,32\%. If on Q3 Indonesia's economic growth still contracted, then certainly Indonesia will go into recession. Indonesian Hotel and Restaurant Association (PHPRI) notes that until April 2020, the total loss of Indonesia's tourism sector reaches IDR 85,7 trillion. Which is marked by thousands of hotels and restaurant closed, and the number of airlines and tour operator experiencing a big loss. According to UNWTO's data report, the number of tourists in the world has decreased to $44 \%$ during a pandemic with comparing this year data with last year.

Within these days of turbulent and uncertain environment -especially caused by COVID-19- organizations are defenseless to problematic occasions [3] which can subvert steadiness and security [4], Lengnick-hall, Beck, and Lengnick-hall (2011)stated that this such troublesome occasions adversely sway the executions of organizations. In this assumption, the idea of resilience [6] has been applied in a lot of fields to evaluate how frameworks adjust with under pressure, adjust to change, and also bounce back after the disruption [7]. According to Holling (1973), Resiliency is the capability of a process to assert the indistinguishability and adjust the crucial structure and function in the look of disruption. Then, Resilience has developed as a significant topic in the travel industry [8], [9] to see how the travel industry framework can be stronger resilience to startle. And furthermore, according to [10] about 
utilizing social capital, we contend that network and resources accessible to firms through their associations with others is likewise a basic element of resilience. Finally, social capital encourages the recuperation of networks and survivors, with quicker recuperation being connected to more grounded social capital.

The study gives the tourism literature in four different constructs. To start with Nahapiet and Ghoshal (1998) study, that how social capital is constructed by utilizing the three components of relational, structural, and cognitive capital, and how these measurements offer an all-encompassing comprehension within the relationship of social capital in the tourism industry literature [12]-[14]. Second, how environmental turbulence become the antecedents for organizational resilience that drive the capacity of organizations to react a changing business sector as a component for managing turbulence environment and increasing performance [15], [16]. Third, studies on the resiliences of the tourism industry has dominated at the macro level, also to analyzing the resilience of the tourism industry destinations [17], communities [18], and the tourism industry subsystems [8]. Fourth, how organizational resilience can improve performance. By proving the components of social capital and environmental turbulence add to organizational resilience that can improve the performance. Furthermore, this concept offers conceptual knowledge on the best way to improve the business in COVID-19 turbulence.

\section{Literature Review}

\subsection{Environmental Turbulence}

Environmental turbulence alludes to the level of the uncertainties and exceptional occasions that happen in the environment where the industry works [19], [20]. Which has three dimensions. First, Market turbulence, Market turbulence defined as the level of progress on the structure of clients or their selection for products and services (Tsai and Yang 2014; Wong 2014). In a dynamic market, clients regularly change their selection, in other words, they will, in general, to look for new products continuously. Second, Technological turbulence, according to Huang and Tsai in 2014 stated that technological turbulence characterized as the level of technological change in the business. Then, Hanvanich, Sivakumar, and Hult characterized technological turbulence as "the degree of change associated with product and process technologies in the industry in which a firm embeds" [21]. Third, Competitive intensity, competitive intensity characterized as the level of rivalry within an industry. Competitive intensity identifies with the activity of competition between firms [22]. Fourth, Pandemic impact, because of the current situation the pandemic COVID-19 that the world experienced with an exploded number of cases, global spread, and travel restrictions spread out. As a result, the government makes policy to travel restrictions and lockdowns, these policy impact to the tourism industry which has eased back down essentially. If look at how the number of worldwide flights dropping by the more than half, and the cancellations level for hotels, campsites, car rental, and destination such as theme park reach more than half [23]. Gossling et al. define pandemic impact as the impact that organizations should observe (including government and local authority policy) and projected in the future.

\subsection{Social Capital}

Based on the social capital theory that Granovetter and Krause et al. written, social capital is an important resource that is gotten from admittance to resources to made accessible within the associations with different firms[24], [25]. It has been recognized there are three important components of social capital with structural, relational, and cognitive [11]. To start with, structural capital has been characterized as a general arrangement between actors within the organization, and the methods through these actors within the organization are connected [11], [26]. Second, to stated that cognitive capital is assembled when actors within organization share comparable desire, vision, and tradition. Third, Relational capital is involving in the quality of relationship, wherein trust, companionship, respect, mutual are implanted and created through organization's repeated transactions with their associate [11], [26], [34]. On the event of the tourism industry, most of the studies for firm-level just utilize one of measurements of social capital [29]. Except from the study that Martínez-Pérez et al. write by using all the three components of social capital, within tourism industry literature all three components have not been examined [13].

\subsection{Organization Resilience}

Organizational resilience is a critical element of competency to contrive for, react to, and recuperate from exigency and crises. Organizational resilience can also be a reference to aggressiveness and a stimulus of cultural adaptive competence. Organizational resilience defined as "a function of an organization's overall situation awareness, management of vulnerabilities, and adaptive capacity in a complex, dynamic, and interconnected environment" [30]. Resilience of the tourism sector is viewed as significant inside a more extensive discussion of organizational resilience since it contrasts from other industries [31]. For instance, the tourism sector is exceptionally sensitive and 
susceptive towards worldwide trending, especially during abrupt of disasters, and also contains of numerous smallmedium enterprises. In addition, in the terms of tourism in the middle of this current pandemic, the tourism sector can be extended in view of concerns and negative impressions of security. Organizational resilience is contained of two components, planning and adaptive capacity [34].

\subsection{SME Performance}

Most of the tourism studies that related toward performance, is measured in normal condition and business condition as usual, including in financial and non-financial performance [35], [36]. Based on studies, it is presently cannot seem to set up the impact of organizational resilience (planning and adaptive capacity) on business performance in COVID-19 pandemic [12], [29]. Based on Liu et al. (2018) stated that Organizational resilience is an asset that drives organizations to adapt with external emergencies and chances, therefore it has possibility to improving business performance. The performance itself can be measured by profit, total sales, and new product success [39].

\section{Research Model}

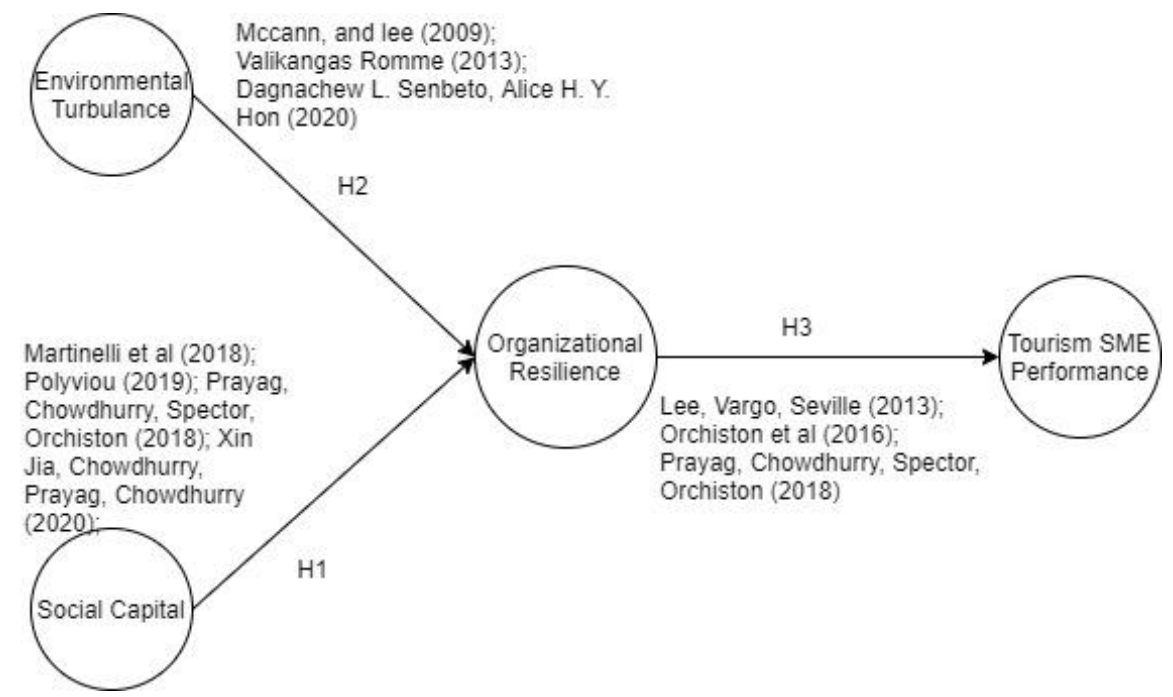

Fig 1. Proposed Research Model

\section{Hypothesis Development}

Within these days of turbulent and uncertain environment -especially caused by COVID-19- organizations are susceptive to disruption [3] which can ruin the stability and safety [4], this such disruption adversely affects the performance of organizations [5]. Within this study, the concept of resilience [6] has been implemented in various fields to evaluate how frameworks adjust to the pressure, adjust to shift and bounce back after the disruptive event [4]. Then, Resilience is the rate of a system to preserve its character and adjust its fundamental structure and capacity when facing a disruption [6]. Resilience has appeared as a significant subject in tourism sector to see how tourism system can serve to be more resilient to shock [8], [9]. And furthermore, about utilizing social capital, we contend that organizations and assets are accessible to firms through their associations with others, it is likewise a basic element of resilience, and also social capital encourages recuperation of organizations, with quicker recoveries being connected to stronger social capital. The hypothesis developed in this study is as follows:

First, how social capital is constructed by utilizing the three elements of relational, structural, and cognitive capital, and how these elements offer a comprehensive understanding inside the relationship of social capital in tourism literature [11].

Hypothesis 1: Social capital is positively influence with organizational resilience 
Second, how environmental turbulence become the antecedents for organizational resilience that drive the ability of organization to respond a changing sector as an instrument for managing turbulent environment and increasing performance especially in pandemic time like this [15], [16].

Hypothesis 2: Environmental turbulence positively influence with organizational resilience

Third, Organizational resilience is a basic element of capacity to arrange for, react to, and recoup from crises and emergencies. Organizational resilience can likewise be a resource of competitiveness and a driver of cultural adaptive competence. McManus et al. define organizational resilience as "a function of an organization's overall situation awareness, management of vulnerabilities, and adaptive capacity in a complex, dynamic, and interconnected environment" [30]. Based on Hall et al. resilience of tourism is viewed as significant inside a of organizational since it contrasts from different businesses. Organizational resilience is involved of two elements, planning and adaptive competency [34].

Hypothesis 3: Tourism SME's resilience is positively influence SME's performance

\section{Methodology and Data Analysis}

Based on do Valle \& Assaker, partial least squares structural equation modeling (PLS-SEM) has developed as a practical other option, because the method stays in its early stages in tourism studies [40]. PLS-SEM offers a few focal points, including that the use of the procedure does not require the standards of normality on multivariate to be fulfilled. Likewise, according to Hair et al., PLS-SEM is appropriate for small sample sizes, if the result that we looking for is to emphasis on theory exploration instead of theory affirmation [41]. This study is still the conceptual study, then in order to obtain the data from the sample, questionnaires will be distributed to respondents with Google Form and give selectively choice that represents the best answer to the sample. Respondent selection criteria are established to represents the best answer that actually represents the current condition. The main criteria for selection defined respondents as SME owners or Managers of SME in Indonesia's tourism sector.

\section{References}

[1] C. M. Hall and S. Page, THE GEOGRAPHY OF TOURISM. 2014.

[2] W. Tourism and O. Unwto, "International Tourism Highlights International tourism continues to outpace the global economy," 2019.

[3] A. M. Knemeyer, W. Zinn, and C. Eroglu, "Proactive planning for catastrophic events in supply chains," vol. 27, pp. 141-153, 2009, doi: 10.1016/j.jom.2008.06.002.

[4] R. Bhamra, S. Dani, and K. Burnard, "Resilience: The concept, a literature review and future directions," Int. J. Prod. Res., vol. 49, no. 18, pp. 5375-5393, 2011, doi: 10.1080/00207543.2011.563826.

[5] C. A. Lengnick-hall, T. E. Beck, and M. L. Lengnick-hall, "Human Resource Management Review Developing a capacity for organizational resilience through strategic human resource management," Hum. Resour. Manag. Rev., vol. 21, no. 3, pp. 243-255, 2011, doi: 10.1016/j.hrmr.2010.07.001.

[6] C. . Holling, "RESILIENCE AND STABILITY OF ECOLOGICAL SYSTEMS,” Annu. Rev. Ecol. Syst., vol. 4, no. 1973, pp. 1-23, 1973.

[7] R. Bhamra, S. Dani, and K. Burnard, "Resilience : the concept, a literature review and future directions," vol. 7543, 2011, doi: 10.1080/00207543.2011.563826.

[8] S. Becken, "Developing a framework for assessing resilience of tourism sub-systems to climatic factors," Ann. Tour. Res., vol. 43, pp. 506-528, 2013, doi: 10.1016/j.annals.2013.06.002.

[9] D. Biggs, C. M. Hall, and N. Stoeckl, "The resilience of formal and informal tourism enterprises to disasters: Reef tourism in Phuket, Thailand," J. Sustain. Tour., vol. 20, no. 5, pp. 645-665, 2012, doi: 10.1080/09669582.2011.630080. 
[10] K. F. Gotham and B. Powers, "Building Resilience: Social Capital in Post-Disaster Recovery," Contemp. Sociol. A J. Rev., vol. 44, no. 1, pp. 30-31, 2015, doi: 10.1177/0094306114562201a.

[11] J. Nahapiet and S. Ghoshal, "1995) and several other authors (Boisot," ^ Acad. ol Manag. Rev., vol. 23, no. 2, pp. 242-266, 1998.

[12] W. D. Dai, Z. E. Mao, X. R. Zhao, and A. S. Mattila, "How does social capital influence the hospitality firm's financial performance? The moderating role of entrepreneurial activities," Int. J. Hosp. Manag., vol. 51, pp. 42-55, 2015, doi: 10.1016/j.ijhm.2015.08.011.

[13] Á. Martínez-Pérez, P. M. García-Villaverde, and D. Elche, "The mediating effect of ambidextrous knowledge strategy between social capital and innovation of cultural tourism clusters firms," Int. J. Contemp. Hosp. Manag., vol. 28, no. 7, pp. 1484-1507, 2016, doi: 10.1108/IJCHM-08-2014-0405.

[14] J. Nieves, A. Quintana, and J. Osorio, "Knowledge-based resources and innovation in the hotel industry," Int. J. Hosp. Manag., vol. 38, pp. 65-73, 2014, doi: 10.1016/j.ijhm.2014.01.001.

[15] D. L. Senbeto and A. H. Y. Hon, "Market turbulence and service innovation in hospitality: examining the underlying mechanisms of employee and organizational resilience," Serv. Ind. J., vol. 0, no. 0, pp. 1-21, 2020, doi: 10.1080/02642069.2020.1734573.

[16] L. Turulja and N. Bajgoric, "Innovation, firms' performance and environmental turbulence: is there a moderator or mediator?," Eur. J. Innov. Manag., vol. 22, no. 1, pp. 213-232, 2019, doi: 10.1108/EJIM-03-2018-0064.

[17] E. Calgaro, K. Lloyd, and D. Dominey-Howes, "From vulnerability to transformation: a framework for assessing the vulnerability and resilience of tourism destinations," J. Sustain. Tour., vol. 22, no. 3, pp. 341-360, 2014, doi: 10.1080/09669582.2013.826229.

[18] A. A. Lew, "Scale, change and resilience in community tourism planning," Tour. Geogr., vol. 16, no. 1, pp. 14-22, 2014, doi: 10.1080/14616688.2013.864325.

[19] K. H. Tsai and S. Y. Yang, "The contingent value of firm innovativeness for business performance under environmental turbulence," Int. Entrep. Manag. J., vol. 10, no. 2, pp. 343-366, 2014, doi: $10.1007 / \mathrm{s} 11365-012-0225-4$.

[20] S. K. S. Wong, "Impacts of environmental turbulence on entrepreneurial orientation and new product success," Eur. J. Innov. Manag., vol. 17, no. 2, pp. 229-249, 2014, doi: 10.1108/EJIM-042013-0032.

[21] S. Hanvanich, K. Sivakumar, and G. T. M. Hult, "The relationship of learning and memory with organizational performance: The moderating role of turbulence," J. Acad. Mark. Sci., vol. 34, no. 4, pp. 600-612, 2006, doi: 10.1177/0092070306287327.

[22] T. Cui, Anna; Griffith, David; Cavusgil, "The Influence and Market Management Multinational of Competitive Intensity on Dynamism Knowledge of Capabilities Subsidiaries Corporation and S . Tamer," Am. Mark. Assoc., vol. 13, no. 3, pp. 32-53, 2005.

[23] S. Gössling, D. Scott, and C. M. Hall, "Pandemics, tourism and global change: a rapid assessment of COVID-19,” J. Sustain. Tour., vol. 0, no. 0, pp. 1-20, 2020, doi: 10.1080/09669582.2020.1758708.

[24] M. Granovetter, "Economic action and social structure: The problem of embeddedness," Sociol. Econ. Life, Third Ed., vol. 91, no. 3, pp. 22-45, 2018, doi: 10.4324/9780429494338.

[25] D. R. Krause, R. B. Handfield, and B. B. Tyler, "The relationships between supplier development, commitment, social capital accumulation and performance improvement," J. Oper. Manag., vol. 25, no. 2, pp. 528-545, 2007, doi: 10.1016/j.jom.2006.05.007.

[26] D. S. Preston, D. Q. Chen, M. Swink, and L. Meade, "Generating Supplier Benefits through BuyerEnabled Knowledge Enrichment: A Social Capital Perspective,” Decis. Sci., vol. 48, no. 2, pp. 248 287, 2017, doi: 10.1111/deci.12220. 
[27] Y. Li, Y. Zhang, and S. Zheng, "Social capital, portfolio management capability and exploratory innovation: evidence from China," J. Bus. Ind. Mark., vol. 31, no. 6, pp. 794-807, 2016, doi: 10.1108/JBIM-09-2012-0166.

[28] W. Tsai and S. Ghoshal, "Social capital and value creation: The role of intrafirm networks," Acad. Manag. J., vol. 41, no. 4, pp. 464-476, 1998, doi: 10.2307/257085.

[29] C. Casanueva, Á. Gallego, and M. Sancho, "Network resources and social capital in airline alliance portfolios," Tour. Manag., vol. 36, pp. 441-453, 2013, doi: 10.1016/j.tourman.2012.09.014.

[30] S. McManus, E. Seville, J. Vargo, and D. Brunsdon, "Facilitated process for improving organizational resilience," Nat. Hazards Rev., vol. 9, no. 2, pp. 81-90, 2008, doi: 10.1061/(ASCE)1527-6988(2008)9:2(81).

[31] C. . Hall, G. Prayag, and A. Amore, Tourism and Resilience: Individual, Organisational and Destination Perspectives. Bristol: Bristol, UK: Channel View, 2018.

[32] C. Orchiston, "Tourism business preparedness, resilience and disaster planning in a region of high seismic risk: The case of the Southern Alps, New Zealand," Curr. Issues Tour., vol. 16, no. 5, pp. 477-494, 2013, doi: 10.1080/13683500.2012.741115.

[33] C. Orchiston and J. E. S. Higham, "Knowledge management and tourism recovery (de)marketing: the Christchurch earthquakes 2010-2011," Curr. Issues Tour., vol. 19, no. 1, pp. 64-84, 2016, doi: $10.1080 / 13683500.2014 .990424$.

[34] A. V. Lee, J. Vargo, and E. Seville, "Developing a tool to measure and compare organizations' resilience," Nat. Hazards Rev., vol. 14, no. 1, pp. 29-41, 2013, doi: 10.1061/(ASCE)NH.15276996.0000075.

[35] T. T. Kim, G. Lee, S. Paek, and S. Lee, "Social capital, knowledge sharing and organizational performance: What structural relationship do they have in hotels?," Int. J. Contemp. Hosp. Manag., vol. 25, no. 5, pp. 683-704, 2013, doi: 10.1108/IJCHM-Jan-2012-0010.

[36] R. Sainaghi and R. Baggio, "Structural social capital and hotel performance: Is there a link?," Int. J. Hosp. Manag., vol. 37, pp. 99-110, 2014, doi: 10.1016/j.ijhm.2013.11.004.

[37] M. Chowdhury, G. Prayag, C. Orchiston, and S. Spector, "Postdisaster Social Capital, Adaptive Resilience and Business Performance of Tourism Organizations in Christchurch, New Zealand," $J$. Travel Res., vol. 58, no. 7, pp. 1209-1226, 2019, doi: 10.1177/0047287518794319.

[38] C. L. Liu, K. C. Shang, T. C. Lirn, K. H. Lai, and Y. H. V. Lun, "Supply chain resilience, firm performance, and management policies in the liner shipping industry," Transp. Res. Part A Policy Pract., vol. 110, pp. 202-219, 2018, doi: 10.1016/j.tra.2017.02.004.

[39] J. C. Narver and S. F. Slater, "The Effect of a Market Orientation on Business Profitability," J. Mark., vol. 54, no. 4, p. 20, 1990, doi: 10.2307/1251757.

[40] P. O. do Valle and G. Assaker, "Using Partial Least Squares Structural Equation Modeling in Tourism Research: A Review of Past Research and Recommendations for Future Applications," $J$. Travel Res., vol. 55, no. 6, pp. 695-708, 2016, doi: 10.1177/0047287515569779.

[41] J. F. Hair, C. M. Ringle, and M. Sarstedt, "PLS-SEM: Indeed a silver bullet," J. Mark. Theory Pract., vol. 19, no. 2, pp. 139-152, 2011, doi: 10.2753/MTP1069-6679190202. 